\title{
Commentary: Why Haven't We Found an Effective Treatment for COVID-19?
}

\author{
Josef Brzoska*, Harald von Eick and Manfred Hündgen \\ Retired, Laupheim, Germany
}

Keywords: COVID-19, coronavirus, interferons - pharmacology, therapeutic use, corticosteroids, clinical trials

\section{A Commentary on}

Why Haven't We Found an Effective Treatment for COVID-19?

By Spicer AJ and Jalkanen S (2021) Front. Immunol. 12:644850. doi: 10.3389/fimmu.2021.644850

\section{INTRODUCTION}

OPEN ACCESS

Edited by:

Paul Roesch,

University of Bayreuth, Germany

Reviewed by:

Piero Sestili,

University of Urbino Carlo Bo, Italy

*Correspondence:

Josef Brzoska

josef.brzoska@t-online.de

Specialty section:

This article was submitted to

Viral Immunology,

a section of the journal

Frontiers in Immunology

Received: 28 May 2021

Accepted: 17 June 2021

Published: 05 July 2021

Citation:

Brzoska J, von Eick $H$ and

Hündgen M (2021) Commentary:

Why Haven't We Found an Effective

Treatment for COVID-19?

Front. Immunol. 12:714175.

doi: 10.3389/fimmu.2021.714175
In their article, Spicer and Jalkanen (1) point out that the search for a single agent to treat COVID-19 is an inappropriate approach. They emphasize that the phase of this disease determines which drug can be therapeutically effective. Patients benefit from the administration of antivirals, such as interferons, only in the early phase of this disease. In the late phase, treatment strategies should be aimed to suppress the cytokine storm. Accordingly, only then can corticosteroids be reasonably administered. In a short phase in-between, a targeted therapy can be applied. Harmful drug interactions have to be avoided, especially between glucocorticoids and interferons, because glucocorticoids can block interferon signalling pathways. Spicer and Jalkanen (1) do not mention the dosages to be used with the different agents. However, these are decisive for treatment success in COVID-19. The use of the most appropriate glucocorticoid dose for suppressing the exaggerated inflammation bears the risk of an increased viral replication. Dexamethasone at a dose of $6 \mathrm{mg}$ given once daily for up to 10 days reduces mortality only in hospitalized patients requiring respiratory support but tends to be harmful in COVID-19 patients with less severe disease (2). Diagnostic markers for the selection and adjustment of the glucocorticoid dosage still have to be determined further. There are also open issues regarding the therapeutic regimen to be used with interferons.

\section{DOSAGES OF INTERFERONS USED IN COVID-19}

Clinical studies in COVID-19 or other severe coronavirus infections have often provided disappointing results regarding the therapeutic efficacy of interferons (3-8). In the trials with systemic administration, interferon alfa and lambda were used as in chronic viral hepatitis, i.e., 3 to 10 million IU three times a week (or an equivalent dose of the PEGylated forms given once weekly) by the subcutaneous route. For the treatment with interferon beta, the dosage chosen was as in multiple sclerosis, i.e., 8 or 12 million IU, respectively, thrice weekly by the subcutaneous route. 
Dose-finding studies with interferons in COVID-19 have not been performed. Several explanations for the failure of interferons in this disease have been provided $(4,5)$, often not considering an inappropriate therapeutic regimen, which we think is one critical factor (3). Only recently, others also suspect a too low dosage and/or a less effective route of administration as potential reasons for the failure of interferons in COVID-19 $(7,8)$. For interferon beta, Jalkanen et al. (9) emphasize the importance of an intravenous administration. However, their recommended daily dosage of $10 \mu \mathrm{g}$ (ca. 2.5 million IU) given as a short-time infusion was neither successful in acute respiratory distress syndrome (10) nor in COVID-19 (11). In our opinion, this dosage and infusion time is not sufficient for interferon beta-1a in acute severe viral diseases. Instead, another therapeutic regimen should be employed according to clinical studies performed about 40 years ago but, apparently, not generally known anymore (3).

\section{EARLY TRIALS WITH INTERFERONS IN ACUTE VIRAL DISEASES}

In 1978, the results of three placebo-controlled studies in herpes zoster treated with native interferon alpha were published (12). In these trials, only the highest dose $(0.51$ million IU per kg body weight, i.e., 36 million IU in a patient with a body weight of $70 \mathrm{~kg}$ ) given daily by intramuscular injections for 5 to 7 days and thus leading to a continuous high serum level was therapeutically effective in contrast to lower daily doses (12 million IU or 3 million IU, respectively, for a patient weighing $70 \mathrm{~kg}$ ). However, this form of high-dose interferon therapy was not pursued any longer since acyclovir received approval for the treatment of herpes zoster in the early 1980s. It was disregarded that the dosage determined for an effective treatment with interferon in herpes zoster could also be indicative for other severe acute viral infections. This approach was only continued with native interferon beta in Germany until the 2000s (3). Because of its distinct tissue affinity, high-dose native interferon beta (25 million IU in an adult) was administered daily for 3 to 5 consecutive days via the intravenous route as a continuous infusion to achieve sufficiently high and persistent serum levels. A daily infusion time of less than $24 \mathrm{~h}$ and lower doses revealed no or only slight therapeutic effects. The potent regimen determined in herpes zoster was also successfully employed to treat other severe acute viral infections (e.g., viral encephalitis) with native interferon beta (3). It has to be emphasized that such a high-dose treatment was typically associated with severe but

\section{REFERENCES}

1. Spicer AJ, Jalkanen S. Why Haven't We Found an Effective Treatment for COVID-19? Front Immunol (2021) 12:644850. doi: 10.3389/fimmu. 2021.644850

2. Horby P, Lim WS, Emberson JR, Mafham M, Bell JL, Linsell L, et al. Dexamethasone in Hospitalized Patients With COVID-19. N Engl J Med (2021) 384:693-704. doi: 10.1056/NEJMoa2021436

3. Brzoska J, von Eick H, Hündgen M. Interferons in the Therapy of Severe Coronavirus Infections: A Critical Analysis and Recollection of a Forgotten transient side effects requiring hospitalization under intensive care conditions.

\section{DOSAGES TO BE USED WITH INTERFERONS IN COVID-19}

Accordingly, we believe that also in COVID-19 a high or the maximum tolerated dose (MTD), respectively, should be given daily for ca. 5 consecutive days if interferon is administered systemically as an antiviral monotherapy (3). However, the MTD of most interferon products currently available has still to be determined, in particular regarding long-term intravenous administration of interferon beta. In COVID-19, a lower dosage than the MTD (as well as the subcutaneous route for interferon beta) can be therapeutically effective only if synergistic effects are utilized, i.e., if interferon is used in combination with other antiviral agents, as demonstrated in some recent clinical studies (13-16). Furthermore, relatively low doses can successfully be employed without concomitant administration of other antivirals if interferon is given by inhalation $(17,18)$. However, interferon applied by this route will probably act on the (upper) respiratory tract only but not on other organs, which are frequently infected by SARS-CoV-2, too, especially in severe cases of COVID-19.

\section{DISCUSSION}

Several studies have shown that timing of interferon administration is one decisive factor in COVID-19 (13-16). A positive treatment effect can be achieved only if interferon is used early in the course of this disease. Furthermore, a therapeutically effective regimen (with a sufficient dose of interferon and an appropriate route of administration) has to be chosen. Simultaneous use of glucocorticoids should be avoided because of the abovementioned reasons. Only if all these aspects are considered, interferon therapy can be successful in COVID-19.

\section{AUTHOR CONTRIBUTIONS}

JB made the literature search and wrote the first draft of the manuscript. This draft was intensively discussed with the two other authors and changed according to their comments. All authors contributed to the article and approved the submitted version.

Therapeutic Regimen With Interferon Beta. Drug Res (2020) 70:291-7. doi: 10.1055/a-1170-4395

4. Sallard E, Lescure FX, Yazdanpanah Y, Mentre F, Peiffer-Smadja N. Type 1 Interferons as a Potential Treatment Against COVID-19. Antiviral Res (2020) 178:104791. doi: 10.1016/j.antiviral.2020.104791

5. Park A, Iwasaki A. Type I and Type III Interferons - Induction, Signaling, Evasion, and Application to Combat COVID-19. Cell Host Microbe (2020) 27:870-8. doi: 10.1016/j.chom.2020.05.008

6. Haji Abdolvahab M, Moradi-Kalbolandi S, Zarei M, Bose D, MajidzadehA K, Farahmand L. Potential Role of Interferons in Treating COVID-19 
Patients. Int Immunopharmacol (2021) 90:107171. doi: 10.1016/j.intimp. 2020.107171

7. Kow CS, Hasan SS. Interferon-Based Therapies in COVID-19. Int Immunopharmacol (2021) 93:107415. doi: 10.1016/j.intimp.2021.107415

8. Jagannathan P, Andrews JR, Bonilla H, Hedlin H, Jacobson KB, Balasubramanian $\mathrm{V}$, et al. Peginterferon lambda-1a for Treatment of Outpatients With Uncomplicated COVID-19: A Randomized Placebo-Controlled Trial. Nat Commun (2021) 12:1967. doi: 10.1038/s41467-021-22177-1

9. Jalkanen J, Hollmén M, Jalkanen S. Interferon beta-1a for COVID-19: Critical Importance of the Administration Route. Crit Care (2020) 24:335. doi: 10.1186/s13054-020-03048-5

10. Ranieri VM, Pettilä V, Karvonen MK, Jalkanen J, Nightingale P, Brealey D, et al. Effect of Intravenous Interferon $\beta$-1a on Death and Days Free From Mechanical Ventilation Among Patients With Moderate to Severe Acute Respiratory Distress Syndrome: A Randomized Clinical Trial. JAMA (2020) 323:725-33. doi: 10.1001/jama.2019.22525

11. Pan H, Peto R, Henao-Restrepo AM, Preziosi MP, Sathiyamoorthy V, Abdool Karim Q, et al. Repurposed Antiviral Drugs for Covid-19 - Interim WHO Solidarity Trial Results. N Engl J Med (2021) 384:497-511. doi: 10.1056/ NEJMoa2023184

12. Merigan TC, Rand KH, Pollard RB, Abdallah PS, Jordan GW, Fried RP. Human Leukocyte Interferon for the Treatment of Herpes Zoster in Patients With Cancer. N Engl J Med (1978) 298:981-7. doi: 10.1056/NEJM197805042981801

13. Hung IF, Lung KC, Tso EY, Liu R, Chung TW, Chu MY, et al. Triple Combination of Interferon beta-1b, Lopinavir-Ritonavir, and Ribavirin in the Treatment of Patients Admitted to Hospital With COVID-19: An OpenLabel, Randomised, Phase 2 Trial. Lancet (2020) 395:1695-704. doi: 10.1016/ S0140-6736(20)31042-4

14. Rahmani H, Davoudi-Monfared E, Nourian A, Khalili H, Hajizadeh N, Jalalabadi NZ, et al. Interferon $\beta-1 \mathrm{~b}$ in Treatment of Severe COVID-19: A
Randomized Clinical Trial. Int Immunopharmacol (2020) 88:106903. doi: 10.1016/j.intimp.2020.106903

15. Davoudi-Monfared E, Rahmani H, Khalili H, Hajiabdolbaghi M, Salehi M, Abbasian L, et al. A Randomized Clinical Trial of the Efficacy and Safety of Interferon $\beta-1 \mathrm{a}$ in Treatment of Severe COVID-19. Antimicrob Agents Chemother (2020) 64:e01061-20. doi: 10.1128/AAC.01061-20

16. Alavi Darazam I, Shokouhi S, Pourhoseingholi MA, Naghibi Irvani SS, Mokhtari M, Shabani M, et al. Role of Interferon Therapy in Severe COVID-19: The COVIFERON Randomized Controlled Trial. Sci Rep (2021) 11:8059. doi: 10.1038/s41598-021-86859-y

17. Zhou Q, Chen V, Shannon CP, Wei XS, Xiang X, Wang X, et al. Interferon$\alpha 2 b$ Treatment for COVID-19. Front Immunol (2020) 11:1061. doi: 10.3389/ fimmu.2020.615275

18. Monk PD, Marsden RJ, Tear VJ, Brookes J, Batten TN, Mankowski M, et al. Safety and Efficacy of Inhaled Nebulised Interferon Beta-1a (SNG001) for Treatment of SARS-CoV-2 Infection: A Randomised, Double-Blind, PlaceboControlled, Phase 2 Trial. Lancet Respir Med (2021) 9:196-206. doi: 10.1016/ S2213-2600(20)30511-7

Conflict of Interest: The authors declare that the research was conducted in the absence of any commercial or financial relationships that could be construed as a potential conflict of interest.

Copyright $\odot 2021$ Brzoska, von Eick and Hündgen. This is an open-access article distributed under the terms of the Creative Commons Attribution License (CC BY). The use, distribution or reproduction in other forums is permitted, provided the original author(s) and the copyright owner(s) are credited and that the original publication in this journal is cited, in accordance with accepted academic practice. No use, distribution or reproduction is permitted which does not comply with these terms. 